\title{
Chemical composition of the periderm in relation to in situ water absorption rates of oak, beech and spruce fine roots
}

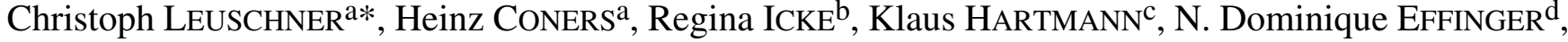 \\ Lukas SCHREIBER ${ }^{\mathrm{c}}$
}

\author{
a Abt. Ökologie und Ökosystemforschung, Albrecht-von-Haller-Institut für Pflanzenwissenschaften, Universität Göttingen, \\ Untere Karspüle 2, 37073 Göttingen, Germany \\ b Abt. Ökologie, Fachbereich 19, Universität Gh Kassel, Heinrich-Plett-Strasse 40, 34132 Kassel, Germany \\ c Institut für Botanik, Ökophysiologie der Pflanzen, Universität Bonn, Kirschallee 1, 53115 Bonn, Germany \\ ${ }^{\mathrm{d}}$ Lehrstuhl Botanik II, Universität Würzburg, Julius-von-Sachs-Platz 3, 97082 Würzburg, Germany
}

(Received 18 March 2002; accepted 11 September 2002)

\begin{abstract}
The water absorption by terminal branch roots of mature oak, beech and spruce trees was measured in situ with miniature sap flow gauges for 11 consecutive days and related to the suberin and lignin content of the fine root periderm. All fine roots contained a well-developed periderm, whereas no primary white roots were present. Mean root water uptake decreased in the sequence beech - spruce - oak. Oak roots contained twice as much suberin and a thicker periderm than beech, and had smaller mean water uptake rates $\left(201 \mathrm{vs} .508 \mathrm{~g} \mathrm{~m}^{-2}\right.$ root surface $\left.\mathrm{d}^{-1}\right)$. However, spruce with 2 to 7 times smaller suberin contents had lower uptake rates $\left(346 \mathrm{~g} \mathrm{~m}^{2} \mathrm{~d}^{-1}\right)$ than beech with more suberin. We conclude that the relationship between periderm chemistry and water absorption is only weak in the three species. Other factors such as hydraulic resistances in the soil-root interface, or the size of water potential gradients may be more influential in regulating root water uptake.
\end{abstract}

lignin / miniature sap flow gauge / root hydraulic conductivity / root surface area / suberin

Résumé - Relation entre la composition chimique du périderme et le taux d'absorption d'eau, in situ, des petites racines de chêne, hêtre et épicéa. On a mesuré, in situ, avec des sondes miniaturisées de flux de sève, pendant 11 jours consécutifs, l'absorption d'eau par les extrêmités des racines de sujets adultes de chêne, hêtre et épicéa. Celle-ci a été ensuite mise en relation avec le contenu en subérine du périderme des petites racines. Toutes ces petites racines présentaient un périderme bien développé, sans racines primaires blanches. Les différentes espèces se classent pour le prélèvement d'eau moyen dans l'ordre décroissant suivant : hêtre, épicéa, chêne. Les racines de chêne contenaient deux fois plus de subérine et comportaient un périderme plus épais que le hêtre. Leur prélèvement d'eau était en moyenne plus faible $\left(201 \mathrm{contre}^{2} 08 \mathrm{~g} \mathrm{~m} \mathrm{~m}^{-2} \mathrm{de}\right.$ surface racinaire et par jour). Cependant, l'épicéa, avec un contenu de subérine 2 à 7 fois inférieur, présentait un taux de prélèvement plus faible ( $346 \mathrm{~g} \mathrm{~m}^{2}$ et par jour) que le hêtre qui a pourtant plus de subérine. Nous en concluons que la relation entre la composition chimique du périderme et l'absorption d'eau n'est que faible pour les trois espèces. D'autres facteurs, tels que la résistance hydraulique à l'interface sol/racines, ou l'importance des gradients de potentiels hydriques, pourraient jouer un rôle plus important pour la régulation du prélèvement d'eau.

lignine / sonde miniaturisée de flux de sève / conductivité hydraulique des racines / surface racinaire / subérine

\section{INTRODUCTION}

Water flow along the soil-plant-atmosphere continuum (SPAC) crosses two major plant-environment interfaces, the root surface where plant water uptake occurs, and the leaf mesophyll surface where transpiration takes place. Despite its importance in the SPAC, relatively little is known about the factors and processes that govern root water uptake. Major advances in our understanding of water uptake by plant roots have been made by introducing pressure probe techniques which allow the measurement of root radial hydraulic conductivity (Lpr) in excised roots (root pressure probe), or cell hydraulic conductivity (Lp) in selected root cells (cell pressure probe) under defined conditions in the laboratory $[40,41]$. By applying these techniques to root systems of various herbaceous and woody plant species, it has been shown that the radial hydraulic conductivity of a root may vary considerably in response to external (e.g. soil moisture, temperature or anoxia) or internal factors (e.g. plant water and nutrient status), but may also change with root development and age [7, 30, 41,

* Corresponding author: cleusch@gwdg.de 
42]. Moreover, comparison among different plant species revealed large differences in Lpr that partly seem to be species-specific. According to root pressure probe data, the Lpr of roots of woody species was smaller by an order of magnitude than that of herbaceous species [41]. Laboratory studies with young excised root systems indicate that different tree species may differ significantly in root Lpr as well: Norway spruce (Picea abies Karst.), sessile oak (Quercus petraea (Matt.) Liebl.) and European beech (Fagus sylvatica L.) differed at least fourfold in Lpr with spruce having the highest and beech the lowest conductivity [34, 43, 44].

A negative relationship between root $\mathrm{Lpr}$ and the amount of suberin in the apoplastic barriers of a root has been found in several investigations with herbaceous roots $[11,38,52]$. Similarly, the large difference in Lpr between herbaceous and woody roots was attributed to a higher degree of suberisation in woody roots [41]. We would expect that the observed differences in Lpr among spruce, oak and beech roots are a consequence of differences in peridermal suberin content in these species. In the root systems of adult trees of these species, white growing roots represent only a low percentage of the total root surface area. The vast majority of fine roots refers to mature suberised roots with the periderm representing the main apoplastic barrier [27]. This situation contrasts with that in most herbaceous roots where endodermis and exodermis play this role.

Pressure probe studies with excised root systems or selected root cells can yield valuable insight into the hydraulic and osmotic properties of root systems but these techniques do not provide sufficient information for predicting in situ water absorption rates of roots in the soil. This is because root hydraulic conductivity is only one factor among others (e.g. hydraulic conductivity of the root-soil interface, conductivity of mycorrhizal hyphae, soil-to-root water potential gradient) which control water flow from the soil into the root. For technical reasons, it has been difficult to quantify water uptake rates of roots in undisturbed soil and, thus, to extrapolate data on root hydraulic conductivity to in situ root water uptake rates. Therefore, the question as to whether differences in root anatomy, chemistry and hydraulics will lead to substantial differences in water uptake rates in a shared soil volume, or whether uptake rates among co-existing plant species are more or less similar, still remains open. There is the possibility that species-specific differences in root hydraulics are simply lost at the level of root water uptake under field conditions if other influential factors are equally or even more important than Lpr. Experimental data on root water absorption, which are needed to solve this problem, are virtually non-existent.

The recently developed miniature sap flow technique provides a welcome opportunity to study tree root water uptake in the soil under in situ conditions [9]. For the first time, a method allows to measure water absorption of tree terminal branch roots in the field without disturbing soil structure, soil moisture and mycorrhizal infection of root tips. In this study, the miniature sap flow technique in combination with root surface area determination was used to compare water absorption per root surface area in three co-existing temperate tree species in a mixed stand. In Central Europe, sessile oak, European beech and Norway spruce have been found to differ in the sensitivity of their leaf water status and growth to soil drought with oak being the least sensitive and spruce the most sensitive species $[2,12,23,48]$. Consequently, spruce is restricted to sites with moderate to high rainfall $(>650 \mathrm{~mm})$ but is absent from regions with low precipitation and/or sandy soils where, in many cases, oak dominates over both spruce and beech [12].

We compare the water absorption rates of terminal branch roots (diameter: 3-4 mm) of co-existing oak, beech and spruce trees measured in situ and relate them to the contents of suberin and lignin in the root periderm. This approach contrasts with earlier laboratory studies on the relationship of radial hydraulic conductivity and the chemical composition of apoplastic transport barriers in plant roots in two ways: (a) chemical data are expressed in relation to root surface area instead of root mass, and (b) water absorption instead of hydraulic conductivity is measured. The following hypotheses are tested: (i) species-specific differences in water absorption rates are related to the suberin and lignin contents of the root periderm, and (ii) suberin and lignin content and, thus, water absorption, are a function of periderm thickness.

\section{MATERIALS AND METHODS}

\subsection{Study site}

Field measurements of root water uptake and sampling of root biomass were conducted in an old-growth mixed beech/oak/spruce stand in the vicinity of Unterlüss in the southern part of the Lüneburger Heide (Lower Saxony, Germany, 52 ${ }^{\circ} 45^{\prime} \mathrm{N}, 10^{\circ} 30^{\prime} \mathrm{E}$ ). The study plot is located in close proximity to forest site no. OB5 where root system structure and root functioning have been studied in mature beech and oak trees by $[5,16,22-24]$. The plot consists of 90- to 100yr-old beech, 180- to 200-yr-old oak, and 80- to 100-yr-old spruce trees at similar stem densities (total number of trees per hectare: ca. 250 ) that form a closed canopy of $28-32 \mathrm{~m}$ in height. Shrub and herbaceous layers are missing.

Located in the diluvial lowlands of NW Germany on Saalian melt water sands ( $115 \mathrm{~m}$ asl), this site is characterised by soil profiles (spodo-dystric cambisols) with thick organic layers (mean depth of the entire organic profile, i.e. Of+Oh horizons, is $72 \mathrm{~mm}$ ). The organic profile is highly acidic with $\mathrm{pH}$ values of 3.0 and 2.6 (in $\mathrm{KCl}$ ) and $\mathrm{Ca}^{2+} / \mathrm{H}^{+}$quotients of 0.2 in the equilibrium soil solution of the upper (Of) and lower organic horizons (Oh), respectively. Measurements using the in situ-soil incubation method [33] showed that about $85 \%$ of the profile total of net nitrogen mineralisation is supplied by these organic horizons, which are much more important for plant nutrition than the mineral soil [24].

The climate is humid sub-oceanic (annual means: $8.0^{\circ} \mathrm{C}$, $800 \mathrm{~mm}$ ). The ground water table is far below the rooting horizon. Periods of low rainfall in summer irregularly lead to substantial water shortage in the sandy mineral soil and in the forest floor. Gravimetric monitoring of soil water content $(\theta)$ in the densely rooted organic Of and Oh layers on the forest floor showed that $\theta$ may be reduced to less than $10 \mathrm{vol} \%$ during summer which corresponds to soil matric potentials $<-1.5$ to $-2.0 \mathrm{MPa}$ in this substrate [22]. In such periods, drought-induced fine root mortality can affect the root systems of beech (but not of oak) in the superficial organic horizons [16, 23].

\subsection{Root sampling and anatomical investigation}

For investigating root anatomy and peridermal chemistry, we extracted 11 branch root systems per species in a $3 \times 3 \mathrm{~m}$ plot bordered by an oak, a beech and a spruce tree separated by about $10 \mathrm{~m}$. 
The stem diameters of the trees were representative of the respective tree species in the stand. The 11 roots were sampled in direct proximity of those roots that were used for root sap flow measurements (see below). We applied compressed air (0.2-0.4 MPa) to completely expose the appending root systems without damaging fine rootlets and peridermal surfaces. The sampled fine root systems had a length of 0.5 to $0.9 \mathrm{~m}$ from the cut to the terminal tip, and were highly branched with a large number of ectomycorrhizal root tips. The root material was sealed in plastic bags and transported to the laboratory.

Five roots were analysed for their diameter/distance relationship, three were used for anatomical investigation, and another three for chemical analysis. The relationship between root diameter and distance from the terminal root tip was measured with a caliper rule at $20 \mathrm{~mm}$ intervals. For anatomical investigation, three branch roots per species were transferred to ethanol $(70 \%)$, dehydrated in a sequence of ethanol/water mixtures, and infiltrated with a solution of Technovit plus hardener (Fa. Kulzer, Frankfurt, Germany). The solid samples were cut with a microtom (Leitz, Wetzlar, Germany) at about 6-7, 70-100, 200-300, 400-500, and 600-800 mm from the terminal root tip (corresponding to root diameters of $0.25,0.50,1.0,2.0$ and $3.0 \mathrm{~mm}$, respectively). The transverse cross-sections were stained with Toluidin blue and Sudan III, and investigated under a microscope (100-1000x) for the following anatomical parameters that may characterise the radial water water flow path in a root: root diameter (mean of largest and smallest diagonal), average periderm thickness, average number of peridermal cell layers, and presence/absence of an endodermis. In most cross-sections investigated, we were able to identify annual growth rings based on the vessel structure in the xylem as well, a parameter used to estimate the minimum age of a root segment.

\subsection{Isolation of cell walls from roots}

Three terminal branch roots per species were used for chemical analysis. Because fresh root material is needed for cell wall analysis, we did not investigate the instrumented roots but extracted branch roots in direct vicinity of those roots that were used for sap flow measurement. The root material was immediately transported to the laboratory and fractionated into the diameter classes $<0.5 \mathrm{~mm}, 0.5-$ $1.0 \mathrm{~mm}$, and 1.0-2.0 mm. The root surface area of all samples was determined with a WinRhizo (Régent, Quebec, Canada) image analysis unit for relating the suberin and lignin content to peridermal surface area. Cell walls of the root segments in the three diameter classes were isolated enzymatically in a manner similar to a method described previously by [39]. Briefly, the freshly harvested root parts were incubated in an enzymatic buffer solution $\left(10^{-2} \mathrm{~mol} \mathrm{~L}^{-1} \mathrm{NaAc}\right.$ at $\mathrm{pH} 4.50,25{ }^{\circ} \mathrm{C}$ ) containing $0.25 \%(\mathrm{w} / \mathrm{v})$ cellulase (Onozuka R-10, Serva, Heidelberg, Germany) and $0.25 \%(w / v)$ pectinase (Macerozyme R-10, Serva). Peridermal cell walls which resisted the enzymatic attack were separated mechanically under a binocular microscope from the lignified stele using two precision forceps after approximately three weeks of maceration. The heavily lignified central cylinder was not subjected to further analysis. Isolated cell wall material was washed twice with borate buffer $\left(10^{-2} \mathrm{~mol} \mathrm{~L}^{-1}\right.$ $\mathrm{Na}_{2} \mathrm{~B}_{4} \mathrm{O}_{7}, \mathrm{pH}$ 9) and deionized water, dried and stored over phosphorus pentoxide for further use.

\subsection{Depolymerization and analyses of suberin and lignin content in isolated peridermal cell walls}

Prior to the chemical depolymerization procedures, suberin and lignin were thoroughly extracted at $60^{\circ} \mathrm{C}$ for $12 \mathrm{~h}$ using chloroform/ methanol (1:1 v/v) and dried again. The dry material was subjected to specific chemical degradation methods depolymerizing either suberin or lignin as described in detail by [49-51]. Chloroform/methanol extracts were used for analysis after solvent evaporation without further purification. After transesterification of the remaining cell wall material, suberin was analysed with methanol borontrifluoride $\left(\mathrm{MeOH} / \mathrm{BF}_{3}\right.$; Fluka) according to [20]. Thioacidolysis was used for the detection of lignin [21]. Three replicate samples per root fraction were investigated.

\subsection{In situ-measurement of root water absorption}

In the past few years, considerable progress has been made in measuring water flux in tree roots under in situ conditions in undisturbed soil (e.g., $[15,17,18,25])$. In this study, the recently introduced miniature sap flow technique $[9,37]$ was used to measure water flow in coarse roots (3-4 mm in diameter) of oak, beech and spruce, and to relate it to the surface of the distal branch root system in order to obtain water absorption rates per root surface area. Details on gauge design, operation, and calibration are given in [9]. Briefly, segments of intact, 3 to $4 \mathrm{~mm}$ roots of mature trees are uncovered by pressurised air $(0.2-0.4 \mathrm{MPa})$ to mount sap flow gauges that are heated continuously by a film resistance heater with 0.04 to $0.07 \mathrm{~W}$. The gauge design is in accordance with $[35,36]$; it applies the heat balance equation to small-diameter roots [37]. The dissipation of heat in distal and radial direction along the root is monitored at time intervals of $15 \mathrm{~s}$ with two sets of thermocouples and a thermopile. Axial water flow in the root is calculated for 15-min averages by solving the heat balance equation for the portion of heat transported with mass flow in axial direction. By cutting the root segment under water and measuring water uptake volumetrically, the gauge data can easily be calibrated by an independent method [9].

In contrast to earlier attempts to measure root sap flow in coarse and large roots with diameters $>10 \mathrm{~mm}$, the miniature sap flow technique allows the investigation of roots that are small enough to be extracted quantitatively with all appending terminal branch roots after measurement. The appending root systems were extracted with pressurised air $(0.2-0.4 \mathrm{MPa})$ and sealed in plastic bags prior to transport to the laboratory. The samples were soaked in demineralised water, and soil residues were removed using a $0.25 \mathrm{~mm}$ wire mesh. Live (biomass) and dead root sections (necromass) were separated under the dissecting microscope using the degree of cohesion of stele and periderm, root elasticity, and colour. A dark periderm and stele, or a white, but non-turgid, stele and periderm, or the complete loss of the stele were used as indicators of root death. These criteria had been established in 20 root samples that were stained with triphenyltetrazolium chloride (TTC) according to the procedure described by [19] and sorted into live and dead fractions according to the presence of the red stain (reduced TTC). To distinguish the three tree species, differences in colour, periderm surface structure and ramification were used [16]. The root surface area of the samples (biomass only) was determined visually with a WinRhizo image analysis unit. Measured root sap flow was then related to fine root surface area (units: $\mathrm{g} \mathrm{m}^{-2} \mathrm{~d}^{-1}$ or $\mathrm{mol} \mathrm{m}^{-2} \mathrm{~s}^{-1}$ ).

Four to five oak, beech and spruce branch roots each (diameter $3-$ $4 \mathrm{~mm}$ ) were selected for study. The 13 studied roots (length to terminal tip: 500 to $900 \mathrm{~mm}$ ) penetrated the organic Of and Oh horizons with a multitude of branch roots. The roots co-existed in the $3 \times 3 \mathrm{~m}$ plot bordered by an oak, a beech and a spruce tree separated by about $10 \mathrm{~m}$. After measurement the roots were traced to these donor trees. A soil coring study in a nearby plot had shown that the fine root systems of the three tree species intermingled completely in this mixed stand [23]; this allows the conclusion that all 13 roots were extracting water in soil of similar soil moisture status. Sap flow measurements were conducted on 11 consecutive days during the summer of 1999 (August 29-September 8). This period was selected for being typical for mid-summer atmospheric and soil moisture conditions. Extensive rainfall during mid of August had saturated the topsoil to soil moisture contents of 23 to $30 \mathrm{vol} \%$. During the measuring period, a high 

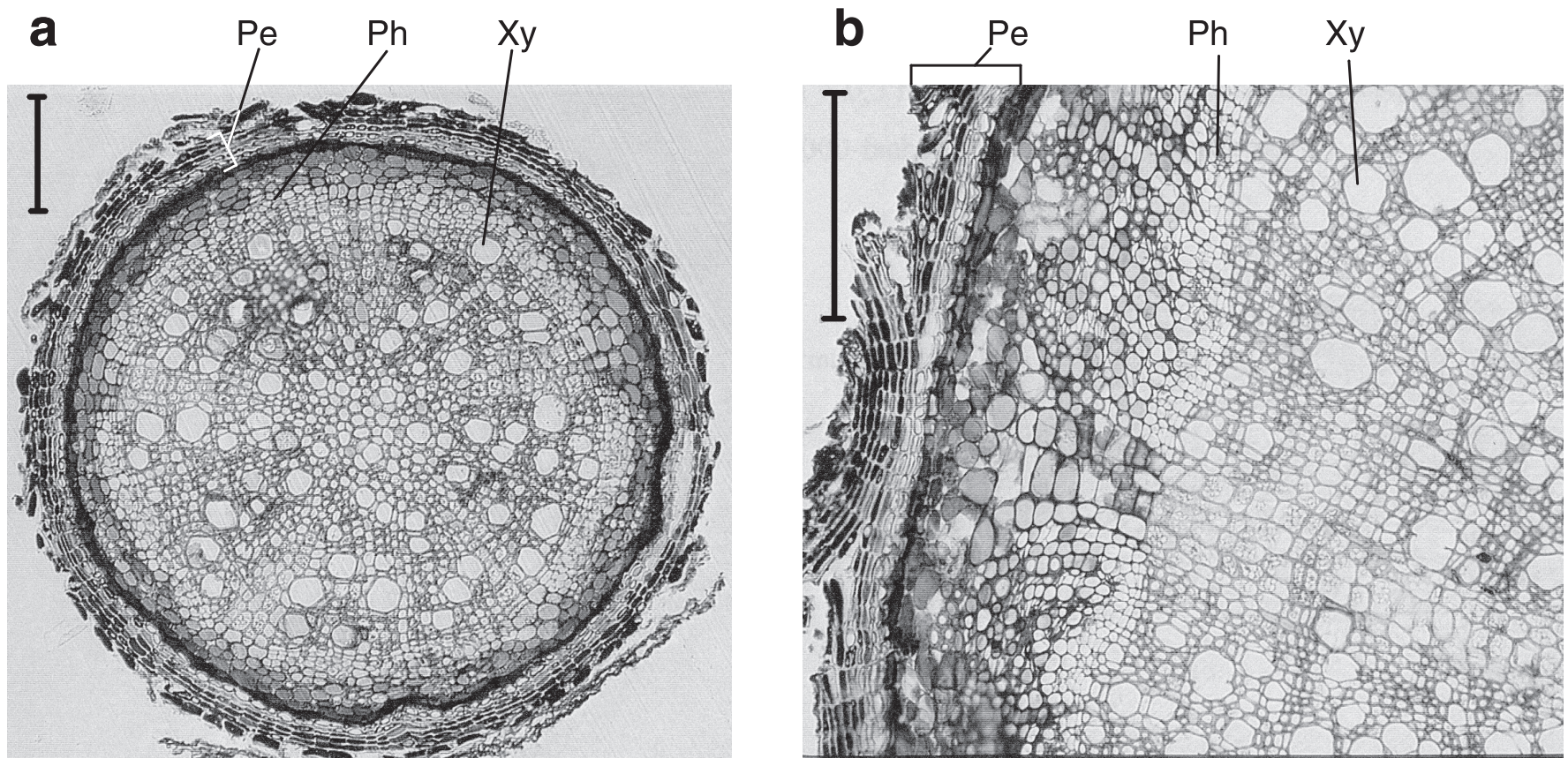

Figure 1. Cross-sections of a beech branch root at $0.5 \mathrm{~mm}(\mathbf{a})$ and $60 \mathrm{~mm}$ distance (b) from the terminal root tip with a multi-layered periderm $(\mathrm{Pe})$, phloem $(\mathrm{Ph})$ and xylem $(\mathrm{Xy})$ being visible. $\mathrm{Bar}=100 \mu \mathrm{m}$.

atmospheric water demand prevailed on bright or partly overcast days, which led to a soil moisture reduction to 17 vol\% on September 8 . Thus, a natural soil drying cycle with moderate drought effects in early September was included in the study. Detailed results of these flux measurements are presented in [11].

\subsection{In situ-estimation of root hydraulic conductivity $L p$}

Root hydraulic conductivity Lp can be obtained from $\mathrm{J}_{\mathrm{s}}$, the volumetric flux density across the root surface (in $\mathrm{m}^{3} \mathrm{~m}^{-2} \mathrm{~s}^{-1}$ ) and the water potential gradient $\Psi_{\text {surface }}-\Psi_{\text {xylem }}$ (in Pa) by equation (1)

$$
\mathrm{Lp}=\mathrm{J}_{\mathrm{S}} /\left(\Psi_{\text {surface }}-\Psi_{\text {xylem }}\right)
$$

if variations in membrane permeability to solutes are neglected. Flux density $J_{S}$ equals root water absorption $\left(J_{V}\right.$, in $\left.\mathrm{m}^{3} \mathrm{~s}^{-1}\right)$ divided by root surface area $A_{r}$ (in $\mathrm{m}^{2}$ ). We attempted to obtain $\mathrm{Lp}$ for the tree branch roots under in situ conditions in the undisturbed rhizosphere. We calculated Lp by recording surface-related water absorption with miniature sap flow gauges, and by measuring the corresponding water potential gradient between root xylem and soil with a pressure chamber and tensiometers. Root water absorption on a surface area basis was recorded at 15 -min intervals for several hours. Five terminal branch roots (length about $100 \mathrm{~mm}$, diameter c. $1 \mathrm{~mm}$ ) were carefully uncovered with pressurised air without damage to root surfaces, cut and the pressure potential of the root xylem immediately measured with a pressure chamber (PMS, Corvallis, Oregon, USA) [28]. The chamber measurements were conducted in a similar manner as done with leaves and completed within 1 min after the cut to minimise errors due to water loss. Three tensiometers with ceramic cups of $20 \times 50 \mathrm{~mm}$ being equipped with pressure transducers recorded the soil matric potential in close proximity of the studied branch roots to obtain a crude estimate of the water potential at the root surface $\left(\Psi_{\text {surface }}\right)$. The tensiometer data were taken every $15 \mathrm{~min}$ and averaged over the three instruments. The potential gradient $\Psi_{\text {surface }}-\Psi_{\text {xylem }}$ was calcu- lated as the difference between pressure chamber and tensiometer readings assuming that the osmotic potential of the soil can be neglected in the very poor sandy soils of this site. We investigated 4 to 5 branch roots per species in the mineral topsoil (0 to $100 \mathrm{~mm}$ ) on 4 days between June 24 and September 9, 1999.

\subsection{Statistical analysis}

We used Scheffé's multiple comparison procedure to test for significant differences among the three species with respect to root water absorption rates, root anatomical properties, and suberin and lignin contents in the periderm. Scheffé's test was also applied for comparing root diameter classes for their suberin and lignin contents in the periderm.

\section{RESULTS}

\subsection{Root anatomy}

All oak, beech and spruce branch roots which were investigated for anatomy showed the mature second stage of tree root development. A thin but clearly differentiated periderm was already present at a distance of about $5 \mathrm{~mm}$ from the terminal root tip. As an example for the three species, Figure 1 shows cross-sections of beech branch roots at two distances from the root tip. The primary stage of root development with stele, endodermis, cortex and exodermis was not found in any of the studied fine roots. Fragments of the endodermis and cortex were only recognised in a few cuts taken from root segments in close proximity to the terminal root tip. Counts of annual growth rings in the root stele indicated a remarkably high age of the fine and coarse roots of the three species. For 


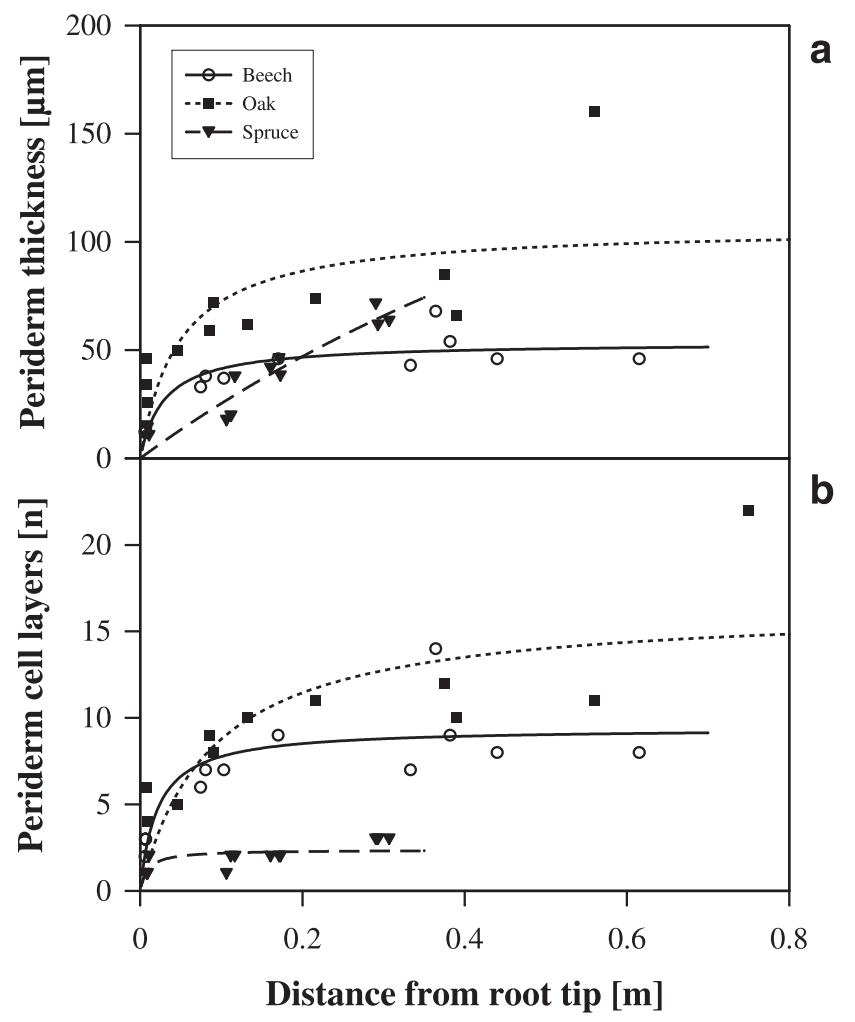

Figure 2. (a) Root peridermal thickness versus distance from the terminal root tip. Square: oak, circle: beech, triangle: spruce ( 3 roots per species). Oak: $\mathrm{y}=89.72 \times \mathrm{x} /(0.025+\mathrm{x}), r=0.62$; beech: $\mathrm{y}=$ $55.56 \times \mathrm{x} /(0.038+\mathrm{x}), r=0.93$; spruce: $\mathrm{y}=323.03 \times \mathrm{x} /(1.17+\mathrm{x})$, $r=0.93$. (b) Number of peridermal cell layers versus distance from the terminal root tip (3 roots per species). Oak: $\mathrm{y}=12.83 \times \mathrm{x} /(0.021+\mathrm{x})$, $r=0.66$; beech: $\mathrm{y}=9.81 \times \mathrm{x} /(0.031+\mathrm{x}), r=0.84$; spruce: $\mathrm{y}=$ $2.39 \times \mathrm{x} /(0.010+\mathrm{x}), r=0.60$.

3-mm roots of beech, oak and spruce, an age of 10 years or more was determined in all samples. Rootlets having a diameter of $1 \mathrm{~mm}$ at 150 to $200 \mathrm{~mm}$ distance from the terminal tip must have been at least 5 years old, and seem to have grown less than $40 \mathrm{~mm}$ per year since their initiation.

Root tips of oak, beech and spruce had diameters of 100 to $300 \mu \mathrm{m}$ and were almost completely infected with ectomycorrhizal fungi. The root diameter of fine branch roots increased continuously with distance from the terminal root tip in the three species and corresponded to increasing numbers of periderm cell layers. Root diameter increase with distance from the tip was largest in spruce, intermediate in oak, and smallest in beech (oak: $\mathrm{y}=0.31 \times \mathrm{x} /(3.7+\mathrm{x}), r=0.92$; beech: $\mathrm{y}=0.27 \times \mathrm{x} /(3.33+\mathrm{x}), r=0.91 ;$ spruce: $\mathrm{y}=0.13 \times \mathrm{x} /(5.66+\mathrm{x})$, $r=0.97$; with y being root diameter $(\mathrm{mm})$ and $\mathrm{x}$ the distance from the terminal tip (m)).

\subsection{Structure of the periderm}

Similar to overall root diameter, root periderm thickness increased non-linearly with distance from the terminal root tip with a rapid increase in the first 50 to $70 \mathrm{~mm}$ and a much slower increase in the subsequent $0.5 \mathrm{~m}$ (Fig. 2a). A multi-

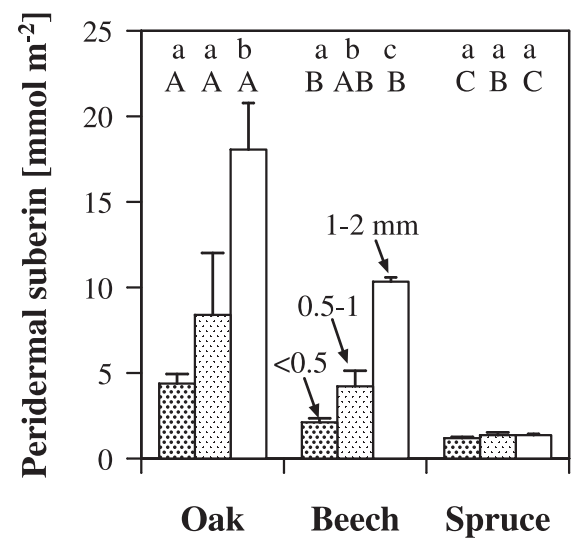

Figure 3. Amounts of aliphatic suberin in isolated peridermal cell walls of oak, beech and spruce root segments expressed on a root surface area basis. Three different diameter classes were distinguished (mean $\pm \mathrm{SD}, n=3$ ). Different capitals indicate significant differences $(P<0.05)$ among the species for a root diameter class, different small letters stand for significant differences among the diameter classes of a species.

layered periderm of 12 to $45 \mu \mathrm{m}$ was present at 60 to $70 \mathrm{~mm}$ distance from the terminal root tip in all species. At $500 \mathrm{~mm}$ distance from the tip, periderm thickness had increased to $50 \mu \mathrm{m}$ in beech and spruce, and to $70 \mu \mathrm{m}$ in oak.

In beech and oak rootlets, the periderm consisted of only 2 to 3 cell layers close to the root tip but increased to 7-8 (beech) or even 10 layers (oak) at distances > $200 \mathrm{~mm}$ (Fig. 2b). Spruce roots, in contrast, had less than 4 peridermal cell layers along the first $400 \mathrm{~mm}$ of a branch root. Thus, at distances $>70 \mathrm{~mm}$ from the tip, oak fine roots possessed a significantly thicker periderm with more cell layers than the two other species. Spruce had a much smaller number of peridermal cell layers than the two broad-leaved trees but the overall periderm thickness was similar to that of beech because its peridermal cork cells were comparably large.

\subsection{Suberin and lignin contents of isolated root peridermal cell wall samples}

Suberin was detected at high concentrations (14-135 $\mathrm{mg} \mathrm{g}^{-1}$ DW or 1-14\%) in isolated peridermal cell walls of oak, beech and spruce roots. When aliphatic suberin content is expressed per root surface area, large differences were evident among the species (Fig. 3). Oak roots had suberin contents that were three times higher in the thinnest root diameter class $(0-5 \mathrm{~mm})$, and by a factor of 10 higher in the largest diameter class (1.0-2.0 mm) than those of spruce roots. Beech fine roots showed values intermediate between spruce and oak for all diameter classes. When the root diameter classes are compared, suberin content showed a large and significant increase with diameter for oak, a moderate increase for beech, and no change with diameter for spruce (Fig. 3). Solvent extracts exhibited large quantities of triterpenoids in concentrations of 1 to $9 \mathrm{~g} \mathrm{~m}^{-2}$, which varied among species and root size classes in a pattern similar to that found for suberin; long-chain aliphatic substances were, however, rare (data not shown). 
Table I. Water absorption rates and related dry mass and surface area of 4 to 5 oak, beech and spruce branch roots as determined with miniature sap flow gauges in the field. Given are mean values ( \pm standard deviation) of measurements on 11 consecutive days in the period August 29-September 8, 1999, in the mixed Unterlüss forest. The roots had a diameter of 3-4 mm at the gauge mounting point; the different branch roots of a species belonged to the same tree individual. The standard deviation results from averaging over different days and roots. Different letters indicate significantly different values among the three species $(P<0.05)$.

\begin{tabular}{lccc}
\hline & Beech & Oak & Spruce \\
\hline Daily water uptake $\left[\mathrm{g} \mathrm{m}^{-2} \mathrm{~d}^{-1}\right]$ & $588 \pm 387^{\mathrm{a}}$ & $200 \pm 109^{\mathrm{a}}$ & $346 \pm 117^{\mathrm{a}}$ \\
Daily water uptake $\left[\mathrm{mmol} \mathrm{m}^{-2} \mathrm{~s}^{-1}\right]$ & $0.38 \pm 0.25$ & $0.13 \pm 0.07$ & $0.22 \pm 0.08$ \\
Variation coefficient for uptake rates [\%] & 65.8 & 54.5 & 33.8 \\
Total surface area $\left[\mathrm{m}^{2}\right]$ & $0.0852 \pm 0.0434^{\mathrm{a}}$ & $0.0949 \pm 0.0483^{\mathrm{a}}$ & $0.0871 \pm 0.0412^{\mathrm{a}}$ \\
Fraction d $<0.5 \mathrm{~mm}[\%]$ & $26.5 \pm 3.8^{\mathrm{a}}$ & $26.6 \pm 3.1^{\mathrm{a}}$ & $2.3 \pm 0.38^{\mathrm{b}}$ \\
Fraction d $0.5-1 \mathrm{~mm}[\%]$ & $41.0 \pm 7.8^{\mathrm{a}}$ & $53.2 \pm 4.5^{\mathrm{b}}$ & $32.7 \pm 3.4^{\mathrm{a}}$ \\
Fraction d $1-2 \mathrm{~mm}[\%]$ & $20.7 \pm 5.5^{\mathrm{a}}$ & $14.8 \pm 2.4^{\mathrm{a}}$ & $41.7 \pm 2.0^{\mathrm{b}}$ \\
Fraction d $>2 \mathrm{~mm}[\%]$ & $11.83 \pm 6.5^{\mathrm{ab}}$ & $5.4 \pm 4.7^{\mathrm{a}}$ & $22.2 \pm 5.3^{\mathrm{b}}$ \\
Total biomass $[\mathrm{g}$ dry weight] & $6.26 \pm 2.8^{\mathrm{a}}$ & $4.6 \pm 1.9^{\mathrm{a}}$ & $9.8 \pm 5.0^{\mathrm{a}}$ \\
Fraction d $<1 \mathrm{~mm}[\%]$ & $46.4 \pm 18.4^{\mathrm{ab}}$ & $65.4 \pm 15.2^{\mathrm{a}}$ & $33.8 \pm 11.5^{\mathrm{b}}$ \\
Fraction d $1-2 \mathrm{~mm}[\%]$ & $19.4 \pm 7.2^{\mathrm{ab}}$ & $16.6 \pm 5.5^{\mathrm{a}}$ & $27.9 \pm 2.8^{\mathrm{b}}$ \\
Fraction d $>2 \mathrm{~mm}[\%]$ & $34.2 \pm 17.27^{\mathrm{a}}$ & $18.0 \pm 14.9^{\mathrm{a}}$ & $38.3 \pm 12.1^{\mathrm{a}}$ \\
Number of roots investigated & 4 & 5 & 4 \\
\hline
\end{tabular}

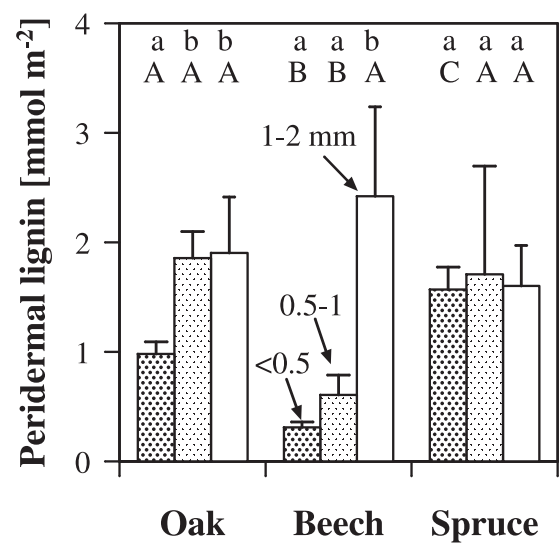

Figure 4. Amounts of lignin in isolated peridermal cell walls of oak, beech and spruce root segments (data expressed on a root surface area basis). Three different diameter classes were distinguished (mean $\pm \mathrm{SD}, n=3$ ). Different capitals indicate significant differences $(P<0.05)$ among the species for a root diameter class, different small letters stand for significant differences among the diameter classes of a species.

Lignin was detected in much smaller quantities in the peridermal cell walls than suberin. In oak and beech roots, the lignin content per surface area was roughly five times smaller than that of suberin (Fig. 4). Relatively large amounts of lignin were found in spruce fine roots where the thinnest rootlets $(<0.5 \mathrm{~mm})$ contained similar amounts of suberin and lignin (about $1.5 \mathrm{mmol} \mathrm{m}^{-2}$ root surface area for both components). Relatively high lignin contents were also detected in the periderm of thicker $(1-2 \mathrm{~mm})$ beech roots.

\subsection{In situ water absorption rates of terminal branch roots}

Concurrent sap flow measurements on 5 oak, 4 beech and 4 spruce small-diameter roots in close vicinity to each other in the organic Of and Oh horizons gave mean water absorption rates of 201 (oak), 588 (beech) and 346 (spruce) $\mathrm{g} \mathrm{m}^{-2} \mathrm{~d}^{-1}$ in the period August 29-September 8, 1999 (averages over all day and night hours, Tab. I). These numbers express the water absorption per total surface area of all appending branch roots (including root tips) distal to the gauge measuring point, and are equivalent to 0.38 (beech), 0.13 (oak) and 0.22 (spruce) mmol water $\mathrm{m}^{-2} \mathrm{~s}^{-1}$. The daily mean absorption rates of beech, oak and spruce roots were not significantly different from each other; however, a trend with beech $>$ spruce $>$ oak existed.

\subsection{Root-soil water potential gradient and $L p$}

In an attempt to quantify root hydraulic conductivity $\mathrm{Lp}$ for roots under in situ-conditions in the soil, measured root water absorption rates were confronted with synchronous measurements of root xylem ( $\left.\Psi_{\text {root }}\right)$ and soil water potentials ( $\left.\Psi_{\text {surface }}\right)$ to characterise the principal driving force of water uptake. On four days during summer 1999, the matric potential of the soil in close proximity to the studied roots varied between -0.008 (moist soil) and $-0.061 \mathrm{MPa}$ (moderately dry soil). The corresponding pressure chamber values of root xylem pressure potential varied between -0.44 and $-1.52 \mathrm{MPa}$ (Tab. II). Based on these measurements, the water potential gradient between root surface and root xylem $\Psi_{\text {surface }}-\Psi_{\text {root }}$ was estimated at 0.4 to $1.5 \mathrm{MPa}$ with largest gradients apparently existing in beech roots. Root hydraulic conductivity was then obtained from $\Psi_{\text {surface }}-\Psi_{\text {root }}$ and the corresponding flux rate $J_{\mathrm{V}}$. The estimated $\mathrm{Lp}$ values of the three species ranged 
Table II. Estimation of root hydraulic conductivity Lp of beech, oak and spruce branch roots under in situ-conditions in the undisturbed soil based on sap flow measurements of root water absorption $\left(J_{v}\right)$, and synchronous water potential measurements in terminal branch roots (pressure chamber values) and in the adjacent soil (tensiometer readings). See equation (1) in text. Different letters indicate significantly different values among the three species on a measuring day $(P<0.05)$. In parentheses: standard deviation.

\begin{tabular}{|c|c|c|c|c|c|}
\hline & $\begin{array}{c}\Psi_{\text {surface }} \\
\mathrm{MPa}\end{array}$ & $\begin{array}{l}\Psi_{\text {root }} \\
\mathrm{MPa}\end{array}$ & $\begin{array}{l}\mathrm{A}_{\mathrm{r}} \\
\mathrm{m}^{2}\end{array}$ & $\begin{array}{c}\mathbf{J}_{\mathrm{V}} \\
\mathrm{m}^{3} \mathrm{~s}^{-1}\end{array}$ & $\begin{array}{c}\mathrm{Lp} \\
\mathrm{m} \mathrm{s}^{-1} \mathrm{MPa}^{-1} \times 10^{-8}\end{array}$ \\
\hline & \multicolumn{5}{|c|}{ June 24} \\
\hline Beech & -0.008 & -0.65 & $0.09(0.05)$ & $1.31(0.40)$ & $2.66(1.18) \mathrm{a}$ \\
\hline Oak & -0.008 & -0.44 & $0.28(0.30)$ & $1.50(1.23)$ & $1.70(1.53) \mathrm{a}$ \\
\hline \multirow[t]{2}{*}{ Spruce } & -0.008 & -0.46 & $0.08(0.06)$ & n.d. & n.d. \\
\hline & \multicolumn{5}{|c|}{ July 12} \\
\hline Beech & -0.052 & -1.52 & $0.09(0.05)$ & $3.77(3.15)$ & $3.22(2.36) \mathrm{a}$ \\
\hline Oak & -0.052 & -0.76 & $0.28(0.30)$ & $1.82(1.19)$ & $1.57(1.50) \mathrm{ab}$ \\
\hline \multirow[t]{2}{*}{ Spruce } & -0.052 & -0.89 & $0.08(0.06)$ & $0.84(0.78)$ & $1.06(0.25) \mathrm{b}$ \\
\hline & \multicolumn{5}{|c|}{ September 2} \\
\hline Beech & -0.030 & -0.81 & $0.09(0.04)$ & $1.72(0.78)$ & $2.87(1.66) \mathrm{a}$ \\
\hline Oak & -0.030 & -0.64 & $0.09(0.05)$ & $0.58(0.15)$ & $1.27(0.67) \mathrm{b}$ \\
\hline \multirow[t]{2}{*}{ Spruce } & -0.030 & -0.45 & $0.09(0.04)$ & $1.34(0.48)$ & $3.94(1.08) \mathrm{a}$ \\
\hline & \multicolumn{5}{|c|}{ September 9} \\
\hline Beech & -0.061 & -1.30 & $0.09(0.04)$ & $1.68(0.64)$ & $1.78(0.96) \mathrm{a}$ \\
\hline Oak & -0.061 & -1.22 & $0.09(0.05)$ & $0.68(0.13)$ & $0.82(0.54) \mathrm{a}$ \\
\hline Spruce & -0.061 & -0.66 & $0.09(0.04)$ & $0.86(0.37)$ & $1.87(0.92) \mathrm{a}$ \\
\hline
\end{tabular}

between 0.82 and $3.94 \times 10^{-8} \mathrm{~m} \mathrm{MPa}^{-1} \mathrm{~s}^{-1}$ and revealed only minor species differences. Oak tended to have smaller Lp values than beech on all four days (difference significant on September 2), and spruce differed from beech on July 12 .

\section{DISCUSSION}

This study profits from recent advances in two technologies which have a high relevance for the study of root hydraulics, (i) the miniaturisation of sap flow gauges which allows calculation of in situ-fluxes per root surface area, and (ii) the chemical analysis of isolated root cell wall samples. By combining these methods we were able, for the first time, to relate in situ root water absorption rates to data on the chemical composition of the periderm, which is the principal apoplastic barrier in mature tree fine roots. In contrast to earlier studies on the chemistry of root cell walls (e.g. [52]), water absorption and cell wall chemistry were both related to root surface area; this enables a direct comparison.

It is remarkable that, even in direct vicinity of the root apex, all fine roots had already reached the mature second stage of root development with a multi-layered periderm. This contrasts with the results of [27] who found 100-110 and 60$70 \mathrm{~mm}$ long sections without a closed periderm sheath in roots of Pinus banksiana and Eucalyptus pilularis seedlings. The nearly complete absence of primary white rootlets in the root systems of our study may be understood in the light of the remarkably great age of the studied terminal branch roots ( $\geq 5$ years for roots of $1 \mathrm{~mm}$ in diameter). It remains unclear whether summer drought (as in July 1999), complete mycorrhizal infection of the root tips $[4,5]$, or other factors have inhibited further growth of the root apex resulting in a comparably high age of the rootlets close to the tip.
In the peridermal cell walls of spruce roots, aliphatic suberin was detected at concentrations comparable to those in the endodermis and hypodermis of corn roots (4-10 and ca. $21 \mathrm{mg} \mathrm{g}^{-1}$, respectively; [50]). Beech and oak roots exhibited significantly larger concentrations (40-60 and 90-135 $\mathrm{mg} \mathrm{g}^{-1}$ ) than both spruce and corn. In contrast to corn roots, aromatic suberin occurred in the root periderm of the three tree species only in traces (data not shown). Lignin was found in much smaller amounts than suberin and showed less clear differences among the three species. Because the studied roots contained no sections with white unsuberised rootlets lacking a periderm, we conclude that water entering these roots must pass through peridermal cell layers which contain at least 1.3 (spruce), 5.0 (beech) or 10.0 (oak) mmol suberin $\mathrm{m}^{-2}$.

Water absorption by the 4 to 5 roots of a species showed a large spatial variability (coefficients of variation: 33.8 to $65.8 \%$ ) despite the fact that the roots grew in a shared soil volume and the tree canopies were exposed to similar radiation loads and atmospheric saturation deficits. According to the much larger flux data set of $[8,10]$, large differences in water uptake rates among neighbouring fine roots of a single tree are a characteristic of the root systems of mature beech, oak and spruce trees and do not reflect inaccuracies of the measuring system. We hypothesise that large spatial variation in tree root water uptake rates is a consequence primarily of small-scale heterogeneity in soil structure and, thus, soil-root hydraulic conductivities.

This novel technique for measuring root water absorption does not allow a precise localisation of water uptake along the root axis. The branch roots of this study (diameter: $3-4 \mathrm{~mm}$ ) had total surface areas of about 0.085 to $0.095 \mathrm{~m}^{2}$ distal to the gauge mounting point. On average, $80 \%$ (oak), $68 \%$ (beech) and $35 \%$ (spruce) of the surface area of the potentially absorbing 
branch roots referred to root sections with diameters $<1 \mathrm{~mm}$, the remaining surface being located on thicker root segments. The specific role of fine and coarse roots in tree water uptake is still a matter of dispute (e.g., [13, 32]), Recent research on water uptake in different zones of onion roots has indicated that apical root regions have a higher resistance to water inflow than the more matured and stronger suberised zones [3]. This agrees with a number of studies who reported a transport of water and ions through peridermal woody roots $[1,6$, $26,46]$. However, it is still an open question whether the dead peridermal cork cells of tree roots are sufficiently permeable to account for this flow, or whether passage occurs through breaks in the periderm [27]. If the number of passage cells or breaks were to determine radial water flow in tree roots, no close relation between peridermal chemistry and water absorption could be expected.

In this study, we observed a factor of about 2 between oak and beech for suberin content in each diameter class, which was close to the ratio of water uptake rate between the two species. The larger suberin content of oak corresponded with a thicker periderm and more periderm cell layers compared to beech. This result might indicate that the degree of suberinisation of peridermal cell walls influences water absorption rates in these species. A comparison of beech and spruce data, however, reveals that spruce with 2 to 6 times smaller suberin contents had lower water absorption rates than beech with more suberin. It appears that the relationship between periderm chemistry or anatomy, and water absorption is only a weak one in the three species.

We estimated root hydraulic conductivities (Lp) for absorbing roots in the soil from measured water fluxes into the root cylinder, and synchronous water potential measurements with tensiometers and pressure chamber in soil and terminal branch roots. The only other available conductivity data for beech, oak and spruce roots were measured at decapitated sapling root systems in the laboratory with the root pressure probe technique yielding data on root radial conductivity (Lpr) [34, 43, 44]. They are compared with our field-derived Lp data because we expect total root hydraulic conductivity (Lp) and Lpr to be more or less similar in the studied roots because root axial conductivity (Kh) typically is one or two orders smaller than Lpr if expressed in the same unit [28]. The two approaches of conductivity measurement yielded roughly comparable results despite largely different experimental setups (Tab. III). However, the species comparison gave contrasting results with root pressure probe data indicating a substantially higher Lpr in spruce than in beech or oak roots which is not supported by our measurements under in situ conditions. In the field, neither Lp nor water absorption rates were higher in spruce than in beech roots. Moreover, the pressure probe Lpr values are not fully consistent with our data on periderm chemistry because they do not reflect the high suberin content of the oak root periderm. If conductivity were a function of suberisation, Lpr values of oak should have been much lower than those of beech which is not visible from the pressure probe data.

One possible explanation of the discrepancy between root pressure probe-derived hydraulic conductivities, anatomical and chemical properties and in situ water absorption rates is the fact that root systems of plants with highly different age (saplings vs. mature trees) were investigated. The high degree
Table III. Root hydraulic conductivity (Lp) of small-diameter roots of beech, oak and spruce estimated under in situ-conditions compared to laboratory measurements of root radial hydraulic conductivity (Lpr, both in $\mathrm{m} \mathrm{s}^{-1} \mathrm{MPa}^{-1} \times 10^{-8}$ ). Lp was measured with miniature sap flow gauges in combination with root and soil water potential measurements by pressure chamber and tensiometer techniques (this study). Lpr was obtained from pressure relaxation measurements with excised root systems of saplings in the laboratory. The field data refer to intact terminal branch roots of mature trees that were absorbing water under in situ conditions in the soil. Oak refers to Q. petraea.

\begin{tabular}{lcc}
\hline & Laboratory-measured $\mathrm{Lpr}^{1}$ & Field-measured $\mathrm{Lp}^{2}$ \\
\hline Beech & $0.35-1.6$ & $1.78-3.22$ \\
Oak & $0.33-1.1$ & $0.82-1.70$ \\
Spruce & $4.9-7.8$ & $1.06-3.94$ \\
\hline
\end{tabular}

1 After Rüdinger et al., 1994; Steudle and Meshcheryatov, 1996; and Steudle and Heydt, 1997. ${ }^{2}$ This study.

of suberisation found in this study is not a characteristic of tree seedlings or saplings that were reared in a glasshouse. Moreover, it has to be kept in mind that root pressure probe measurements are conducted under artifical conditions with water being forced through the root by modification of xylem pressure or applying osmotic gradients. This setup is highly different from natural potential gradients that exist in the rhizosphere.

We suggest that the most likely explanation of a partial mismatch among root hydraulics, chemical and anatomical properties, and measured water absorption is the fact that additional factors, which may control water flow into the root, have to be considered during the upscaling process from laboratory to field. Root chemical and anatomical properties and even $\mathrm{Lpr}$ may be less important in controlling in situ water absorption than they are in a laboratory setup with excised root systems. (i) The tips of oak, beech and spruce fine roots are nearly completely infected by ectomycorrhizal fungi. In a few studies, ectomycorrhizas have been found to increase hydraulic conductance of tree roots (e.g. [29, 34]); whereas other authors reported negative or neutral effects [31]. An only limited effect on water uptake would be understandable because mycorrhizae affect the outer part of the root rather than the stele and endodermis which, for geometric and other reasons, may represent the bottle neck. (ii) In dry soil, the hydraulic conductivity of the rootsoil contact zone has been found to be considerably lower than that of the path between the root surface and the stele due to incomplete root-soil contact in certain substrates [47]. A very rapid decrease in hydraulic conductivity with increasing water loss is to be expected in soil substrates with a high porosity, such as the organic forest floor horizons of this study. Root contraction in drought-stressed plants may contribute to a low hydraulic conductivity in the perirhizal soil [14]. Therefore, it is possible that a low conductivity in the root-soil interface has masked variable Lp values of the three species under field conditions in this study. (iii) Water absorption is also dependent on the water potential in the root xylem. Comparative measurements with the pressure bomb in terminal branch roots of coexisting oak, beech and spruce roots showed considerable 
differences among the species during periods of drought which may be the result of differences in either leaf water status or stem hydraulic conductivity [8]. Comparative measurements of root water absorption in different soil types and during periods of low and high soil water deficits are needed to assess the influence exerted by variable soil-root water potential gradients and soil-root hydraulic conductivities on root water absorption. (iv) It has recently been suggested that a fine regulation of root water uptake is provided by water channels (aquaporins) in the cell-to-cell passage of water flow in roots $[7,45]$. Opening and closing of the channels could alter Lpr mainly when the water potential gradient has an osmotic nature. However, a significant effect of water channels on conductivity could not be detected in corn roots [52]. Whether water channels are a significant factor, that could explain speciesspecific differences in water absorption among peridermal tree roots, remains unclear.

There is the possibility that elevated suberin and lignin contents in tree fine roots are more relevant for root drought tolerance than they are for root water absorption. Several authors have found an increase in suberisation of the endo- or exodermis in herbaceous plant roots following drought or salinity stress $[11,30]$. Oak fine roots may be classified as rather drought tolerant in the Unterlüss forest because sessile oak fine root systems showed a more surface-directed distribution pattern in the topsoil, and were less affected by droughtinduced fine root mortality during a dry summer, than coexisting beech roots $[16,23]$. This may correspond to the high aliphatic suberin content of oak root cell walls. A low suberin content in Norway spruce roots coincided with a high drought sensitivity of this species in Central Europe [12]. Experimental testing in field studies with carefully controlled drought intensities is needed to show whether oak, beech and spruce indeed differ with respect to drought sensitivity of fine root growth and mortality. Finally, it is necessary to increase the spatial resolution of water uptake measurements because the importance of different root diameter classes in root water absorption is still unknown.

Acknowledgements: This work was supported by the Deutsche Forschungsgemeinschaft (DFG) with grants to C.L. and L.S. (the latter as part of the priority program "Apoplast").

\section{REFERENCES}

[1] Addoms R.M., Entrance of water into suberized roots of trees, Physiol. Plant 21 (1946) 109-111.

[2] Backes K., Leuschner Ch., Leaf water relations of competitive Fagus sylvatica L. and Quercus petraea (Matt.) Liebl. trees during four years differing in soil drought, Can. J. For. Res. 30 (2000) 335346.

[3] Barrowclough D.E., Peterson C.A., Steudle E., Radial hydraulic conductivity along developing onion roots, J. Exp. Bot. 51 (2000) 547-557.

[4] Bledsoe C.S., Zasoki R.J., Effects of ammonium and nitrate on growth and nitrogen uptake by mycorrhizal Douglas-fir seedlings, Plant Soil 71 (1983) 445-454.

[5] Büttner V., Leuschner Ch., Spatial and temporal patterns of fine root abundance in a mixed oak-beech forest, For. Ecol. Manage. 70 (1994) 11-21.
[6] Chung H.-H., Kramer P.J., Absorption of water and ${ }^{32} \mathrm{P}$ through suberized and unsuberized roots of Loblolly pine, Can. J. For. Res. 5 (1975) 229-236.

[7] Clarkson, D.T., Carvajal M., Henzler T., Waterhouse R.N., Smyth A.J., Cooke D.T., Steudle E., Root hydraulic conductance: diurnal aquaporin expression and the effects of nutrient stress, J. Exp. Bot. 51 (2000) 61-70.

[8] Coners H., Wasseraufnahme und artspezifische hydraulische Eigenschaften der Feinwurzeln von Buche, Eiche und Fichte: In situ-Messungen an Altbäumen. Ph.D. thesis, Göttingen University, Germany, 2001.

[9] Coners H., Leuschner Ch., Water absorption by tree fine roots measured in situ with miniature sap flow gauges, Funct. Ecol. 16 (2002) 696-703.

[10] Coners H., Leuschner Ch., Daily and seasonal variation of root water uptake by three temperate tree species in its dependence on plant, soil and atmospheric factors. Submitted.

[11] Cruz R.T., Jordan W.R., Drew M.C., Structural changes and associated reduction of hydraulic conductance in roots of Sorghum bicolor L. following exposure to water deficit, Physiol. Plant 99 (1992) 203-212.

[12] Ellenberg H., Vegetation Mitteleuropas mit den Alpen in ökologischer, dynamischer und historischer Sicht. 5th ed. Stuttgart, Germany: Ulmer Verlag, 1996.

[13] Escamilla J.A., Comerford N.B., Measuring nutrient depletion by roots of mature trees in the field, Soil Sci. Soc. Am. J. 62 (1998) 797-804.

[14] Faiz M.A., Weatherley P.E., Root contraction in transpiring plants, New Phytol. 92 (1982) 333-343.

[15] Green S.R., Clothier B.E., Root water uptake by kivifruit vines following partial wetting of the root zone, Plant Soil 173 (1995) 317-328.

[16] Hertel D., Das Feinwurzelwerk von Rein- und Mischbeständen der Rotbuche : Struktur, Dynamik und interspezifische Konkurrenz, Dissertationes Botanicae 317 (1999) 1-190.

[17] Howard S.B., Ong C.K., Black C.R., Khan A.A.H., Using sap flow gauges to quantify water uptake by tree roots from beneath the crop rooting zone in agroforestry systems, Agrofor. Syst. 35 (1997) 15-29.

[18] Jackson R.B., Sperry J.S., Dawson T.E., Root water uptake and transport: using physiological processes in global predictions, Trends Plant Sci. 5 (2000) 482-488.

[19] Knievel D.P., Procedure for estimating ratio of living and dead root dry matter in root core samples, Crop Sci. 13 (1973) 124-126.

[20] Kolattukudy P.E., Agrawal V.P., Structure and composition of aliphatic constituents of potato tuber skin (suberin), Lipids 9 (1974) 682-691.

[21] Lapierre C., Pollet B., Monties B., Thiacidolysis of spruce lignin: GC-MS analysis of the main dimers recovered after Raney nickel desulphurication, Holzforschung 45 (1991) 61-68.

[22] Leuschner Ch., Changes in forest ecosystem function with succession in the Lüneburger Heide, in: Tenhunen J., Hantschel R., Lenz R. (Eds.) Ecosystem Approaches to Landscape Management in Central Europe, Ecol. Stud. 147 (2000) 517-568.

[23] Leuschner Ch., Hertel D., Coners H., Büttner V., Root competition between beech and oak: a hypothesis, Oecologia 126 (2001) 276-284.

[24] Leuschner Ch., Rode M.W., The role of plant resources in forest succession: changes in radiation, water and nutrient fluxes, and plant productivity over a 300-yr-long chronosequence in NW Germany, Perspectives in Plant Ecology, Evolution and Systematics 2 (1999) $103-147$.

[25] Leuschner Ch., Backes K., Hertel D., Schipka F., Schmitt U., Terborg O., Runge M., Drought responses at leaf, stem and fine root levels of competitive Fagus sylvatica L. and Quercus petraea (Matt.) Liebl. trees in dry and wet years, For. Ecol. Manage. 149 (2001) 33-46.

[26] MacFall J.S., Johnson G.A., Kramer P.J., Comparative water uptake by roots of different ages in seedlings of loblolly pine (Pinus taeda L.), New Phytol. 119 (1991) 551-560. 
[27] McKenzie B., Peterson C.A., Root browning in Pinus banksiana Lamb. and Eucalyptus pilularis Sm. 2. Anatomy and permeability of the cork zone, Bot. Acta 108 (1995) 138-143.

[28] Moreshet S., Huang B., Huck M.G., Water permeability of roots, in: Waisel Y., Eshel A., Kafkafi U. (Eds.) Plant Roots, The Hidden Half, New York, Marcel Dekker, 1996, pp. 659-768.

[29] Muhsin T.M., Zwiazek J.J., Ectomycorrhizas increase apoplastic water transport and root hydraulic conductivity in Ulmus americana seedlings, New Phytol. 153 (2002) 153-158.

[30] North G.B., Nobel P.S., Radial hydraulic conductivity of concentric root tissues of Agave deserti Engelm. under wet and drying conditions, New Phytol. 130 (1996) 47-57.

[31] Oertli J.J., Transport of water in the rhizosphere and in roots, in: Waisel Y., Eshel A., Kafkafi U. (Eds.) Plant Roots, The Hidden Half, Marcel Dekker, New York, pp. 607-634.

[32] Peterson C.A., Cholewa E., Structural modification of the apoplast and their potential impact on ion uptake, Z. Pflanzenernähr. Bodenkd. 161 (1998) 521-531.

[33] Raison R.J., Connell M.J., Khanna P.K., Methodology for studying fluxes of soil mineral-N in situ, Soil Biol. Biochem. 19 (1987) 521530.

[34] Rüdinger M., Hallgren S.W., Steudle E., Schulze E.-D., Hydraulic and osmotic properties of spruce roots, J. Exp. Bot. 45 (1994) 1413-1425

[35] Sakuratani T., A heat balance method for measuring water flux in the stem of intact plants, J. Agric. Meteorol. 37 (1981) 9-17.

[36] Senock R.S., Ham J.M., Heat balance sap flow gauge for small diameter stems, Plant Cell Environ. 16 (1993) 593-601.

[37] Senock R.S., Leuschner Ch., Axial water flux dynamics in small diameter roots of a fast growing tropical tree, Plant Soil 208 (1999) $57-71$.

[38] Stavosky E., Peterson C.A., Effects of drought and subsequent rehydration on the structure, vitality and permeability of Allium cepa adventitous roots, Can. J. Bot. 71 (1993) 700-707.

[39] Schreiber L., Breiner H.-W., Riederer M., Düggelin M., Guggenheim R., The Casparian strip of Clivia miniata Reg. roots: isolation, fine structure and chemical nature, Bot. Acta 107 (1994) 353-361

[40] Steudle E., Pressure probe techniques: basic principles and application to studies of water and solute relations at the cell, tissue and organ level, in: Smith J.A.C., Griffiths H. (Eds.), Water deficits: plant responses from cell to community, Oxford, England: Bios Scientific Publishers, 5-36, 1993.

[41] Steudle E., Water uptake by plant roots: an integration of views, Plant Soil 226 (2000a) 45-56.

[42] Steudle E., Water uptake by roots: effects of water deficit, J. Exp. Bot. 51 (2000b) 1531-1542.

[43] Steudle E., Heydt H., Water transport across tree roots, in: Rennenberg H., Eschrich W., Ziegler H. (Eds.), Trees - Contributions to Modern Tree Physiology, Leiden, The Netherlands: Backhuys Publishers, 1997, pp. 239-255.

[44] Steudle E., Meshcheryakov A.B., Hydraulic and osmotic properties of oak roots, J. Exp. Bot. 47 (1996) 387-401.

[45] Steudle E., Peterson C.A., How does water get through roots? J. Exp. Bot. 49 (1998) 775-788.

[46] Van Rees K.C.J., Comerford N.B., The role of woody roots of slash pine seedlings in water and potassium absorption, Can. J. For. Res. 20 (1990) 1183-1191.

[47] Veen B.W., Van Noordwijk M., De Willigen P., Boone F.R., Kooistra M.J., Root-soil contact of maize, as measured by a thinsection technique, Plant Soil 139 (1992) 131-138.

[48] Von Wilpert K., Die Jahrringstruktur von Fichten in Abhängigkeit vom Bodenwasserhaushalt auf Pseudogley und Parabraunerde, Freiburger Bodenkundliche Abhandlungen 24 (1990) 1-184.

[49] Zeier J., Schreiber L., Chemical composition of hypodermal and endodermal cell walls and xylem vessels isolated from Clivia miniata: identification of the biopolymers lignin and suberin, Physiol. Plant 113 (1997) 1223-1231.

[50] Zeier J., Schreiber L., Comparative investigation of primary and tertiary endodermal cell walls isolated from the roots of five monocotyledoneous species: chemical composition in relation to fine structure, Planta 206 (1998) 349-361.

[51] Zeier J., Ruel K., Ryser U., Schreiber L., Chemical analysis and immunolocalisation of lignin and suberin in endodermal and hypodermal rhizodermal cell walls of developing maize (Zea mays L.) primary roots, Planta 209 (1999) 1-12.

[52] Zimmermann M.H., Hartmann K., Schreiber L., Steudle E., Chemical composition of apoplastic transport barriers in relation to radial hydraulic conductivity of corn roots (Zea mays L.), Planta 210 (2000) 302-311. 